\title{
Applying Cryptography in E-Banking Security
}

\author{
N. Priya, P. Nandhini, D.Jeya Priya, Nikita sharma
}

\begin{abstract}
Electronic Banking that is furthermore define as $E$ -Banking. It could be a supply of getting information concerning bank and its various administrations by means of web. $E$ - Banking is at present the crucial substance of Banking administrations. Information innovation has purchased real changes inside the operational setting of the Banking sector. The creative strategies upheld by banks square measure inside the kind of programmed teller machine Machines - ATM's, on-line Banking, phone Banking, Mobile Banking and so on,. the wellbeing and protection of the learning is that the real concern on the whole web Banking techniques. Additionally the web keeping money industries inclined to assaults related with client validation. The objective of this paper is to discuss various encoding systems upheld science advancements and audit various methods for security in E-Banking
\end{abstract}

Keywords-E-banking, Security, Encryption, Decryption, Cryptography

\section{INTRODUCTION}

Digitally keeping money that gives various banking benefits through web changed the manners by which of business led in banks definitely. Furthermore referred to as on-line saving money, it amazingly helped in decrease of managing an account managing costs and expanding the points of interest to clients by various incorporated administrations. Security and protection region unit the most anticipated choices inside the field of on-line saving money. On-line dealings need most extreme security to stay away from feasible untrustworthy exchange of any sort. each sort of learning and various administrations for exchanges territory unit offered for the clients through web. The encoding of learning is that the supply of security and protection amid this on-line keeping money. the protections gave inside the sort of catchword, stick code, biometric, computerized signature, steganography and so on. The banks need to mirror extra and contribute on learning and information security as a result of the consistent flood in use of on-line and portable channels [4] and in light of the differed related dangers. Dealing with the security in on-line saving money and telephone keeping money is that the most astounding test than contrasted with alternative dealing administrations. Cryptography envelops a noteworthy job inside the banks and elective onetaryservice organizations to ensure them that each one their vital various information

Revised Manuscript Received on July 22, 2019.

N.Priya, Department of CSE, Bharath Institute of Higher Education and Research, Chennai, Tamilnadu, India.

Ms. P. Nandhini Department of CSE, Bharath Institute of Higher Education and Research, Chennai, Tamilnadu, India

D.Jeypriya, Department of CSE, Bharath Institute of Higher Education and Research, Chennai, Tamilnadu, India

Nikita Sharma, , Student,Department of CSE, Bharath Institute of Higher Education and Research, Chennai, Tamilnadu, India exchanges zone unit prepared immovably. It makes a message muddled or messy to everyone but to real clients and it's furthermore an approach to grow how to show the supply of messages and assure that the messages are not in analysis[8],[10],[12]

The encoding calculations were utilized for all the insurance forms and in this manner the calculations required the work of programming based methods that gave counter procedures to stay away from security assaults. The banks as of now zone unit consolidating encoding, bolstered examination cryptologic strategies [3] into their correspondence channels in order to verify the data managing and stay away from controls and have verified system correspondence and exchanges. [2 ],[ 4],[6]

\section{LITERTURE REVIEW}

The review is focused on giving the learning related

to innovation based generally administrations of banks and furthermore the security methods custom fitted comprehensively. On-line saving money at present a days plays an imperative job at each dimension on everyday exchanges. Goldreich [1] in 1998 talks about the significance of cryptography, that is fundamentally acclimated keep the information mystery. [3] has talks on the crypto logical strategies utilized in managing an account framework to have verified exchanges. [4] offers information on various electronic exchanges that are available numerous assortments of charge/Visas and so forth., Associate in Nursing systems acclimated prevent an unapproved individual from getting to the private learning or information of the client. In 2000, a system unit N. Haller [6] planned a1 Time positive distinguishing proof framework to counter the assaults on systems administration frameworks used by real clients. The confirmation strategy incorporates age of single utilize just once passwords, that square measure nothing anyway pass phrases travel by various cycles. SMS based generally portable keeping money [7] to fortify the wellbeing was referenced and furthermore the use of rhombohedral AES, propelled cryptography standard, sepulcher ological calculations to verify SMS. In 2009, Embedded crypto-biometric validation subject is mix of the cryptography and biometric system to help the measure of security.For individual confirmation was anticipated by [11]. By blend of the cryptography that scrambled the photos then transmitted to the safe channel and by abuse biometric that the photos of unique mark nonheritable from the client encoded for the confirmation. In 2014, Avhad, Prashant R., and R. Satyanarayana [10] referenced anyway a center man aggressor will faucet the 
net channel among client and server all through the strategy for dealings and may separate the information and discover client subtleties like passwords. [25],[27],[29]

\section{RESULTS AND DISCUSSIONS}

\section{A. ATM}

The ATM Machine ended up being an essential innovative advancement that empowered cash foundations to create administrations to their clients in an extremely $24 \mathrm{X} 7$ environment. The ATM has expanded the comfort of customers by empowering them to get to their money where required from the nearest ATM. the fundamental develop is that somebody with an authentic card will conduct any managing an account amass activity while not visiting a branch. They're acknowledged for its benefit to the buyers, cost effectiveness to the bank and most fundamentally it's an extremely secure managing an account approach. The elements of ATMs rely on approval of a gathering activity by the bank by means of a protected correspondences organize. Moving from operational frameworks to Microsoft Windows ${ }^{\circledR}$ innovation has semiconductor diode to bigger property and interconnectivity of ATMs. Brobdingnagian systems - including ATMs, branch frameworks, telephone frameworks and elective foundation associated by means of the Internet-are focuses of sensible security dangers. Intelligent aggressors grasp programmers UN office produce infections meant to bargain AN ATM,s programming and programmers UN office introduce malware to damage the secrecy, respectability or validity of exchange related data. Fluctuated cryptography calculations square measure planned into the correspondence system to thwart unapproved exchanges. Directly the stick that is entered on ATM should be recover to scrambled example before sending it over the system. Every ATM has encoded cushion that scramble stick on ATM. Physically the keys square measure more on ATM prior, as of now these keys will come back from switch (frameworks to that $\mathrm{ATM}^{\mathrm{ee}} \mathrm{s}$ square measure associated).

\section{B. VARIOUS CARDS - (Debit, Credit Or Smart )}

Electronic card permits a cardholder to form a payment or a sale by electronic store exchange. The normal styles of cards are charge cards and platinum cards. Electronic cards are once in a while enriched plastic cards, that fits the ISO/IEC 7810 ID- ordinary. The Electronic cards now and then have Associate in Nursing decorated card assortment that comp lies with the ISO/IEC 7812 rundown typical. Attractive stripes were presented on check cards inside the Nineteen Seventies once the ATMs came in. The mag tape may store card learning that might be peruse by direct contact and by swiping on the machine. Any way it totally was direct to jab into information encoded on attractive stripe. Attractive stripe charge cards are a great deal of less demanding to fake than chip and PIN assortments. As attractive stripe cards don ${ }^{e e}$ need any PIN , they give no assurance against any sensibly cheats. The reason that the chip and PIN cards arsafer than mag tape cards is that they need a four-digit PIN for approval. it's the best thanks to apprehend that the board holder is that the genuine proprietor of the card. All the data and correspondences are protected by cryptography, making chip and PIN cards harder to hack. The EMV great chip wherever EMV represents Europay, MasterCard and Visa, the 3 firms that made this semiconductor confirmation framework for credit, charge and ATM cards is that the little chip brightened ON CARDS. Utilizing great cards could be an assortment of strong security verification. [31],[33],[35]

There are issues related with the wellbeing in validity and trustworthiness. The shortcomings of existing confirmation subject like word and personal recognizable proof number helped fraudsters to take info| the knowledge |the data keep in ATM smartcards that reason the loss of money in financial records and individual data abuses. The moderation of the confirmation issues on the ATM positive distinguishing proof propelled towards the implanted biometric and cryptography approaches .The premier imaginative and dependable in positive recognizable proof security came in assortment of Fingerprint biometric. [1],[3],[5]

\section{MOBILE BANKING}

Once positive distinguishing proof (OTP) is utilized to demonstrate one's personality over the wireless channel. a one Time positive ID (OTP) might be a positive recognizable proof that is legitimate for under one Login Session or gathering activity. The OTP generate to user's enlisted portable assortment as SMS is most normally utilized procedure for client confirmation. The client will get the OTP by means of instant message. OTP SMS that is one in everything about reasonable technique for causation a

Stick, might be a framework to send to anyone $\mathrm{s}$ convenient a "one time secret key" for his or her money exchange and installment tasks and web Banking login. Neither the individual nor anybody else will use for a second time these 5 digit just once passwords created by OTP SMS anyway the OTP SMS sent more often than not as plain content is at risk to fluctuated assaults on the channel. The client needs to perceive the PIN to peruse the OTP. The client will continue with the business bunch activity, Exclusively when this confirmation. This strategy gives start to finish encryption of the OTP SMS. The OTP that is encoded is decoded given thatthe four digit PIN entered by the client at his portable is right. Since the PIN is seen exclusively to the client, it gives two dimensions of validation. given that PIN and OTP square measure right the client is permitted to continue with the m-saving money gather activity that he started. The OTP created is encoded exploitation the amazing AES rule. The created OTP cost is scrambled exploitation amazing AES rule and sends it to users. AES is partner unvaried and uneven key square figure that utilizes 3 keys qualities of 128, 192 and 256 bits. The AES utilizes 128 bits as a square to code and decipherment. it's one in everything about rightcryptography calculations to monitor individual data. [7]. The encoded AES apparatus 
changes over the information plain content to figure content amid an assortment of required redundancies bolstered the coding key. The AES decodetechnique utilizes a comparable technique to adjust the figure content back to the principal plain content exploitation a similarcoding key. it's frightfully hard to hinder even exploitation animal power assault. The encoded choosepositive recognizable proof is send to versatile through Bluetooth innovation or electronic hardware [6]. the drawback of this procedure is that it's enormous framework load for coding and decipherment.

\section{CONCLUSION}

Later on, the \{requirement for learning security and honesty can in any case require our watchful idea and thought. For wrapping up vital exchanges like store exchanges, the banks, at the littlest sum, should execute solid and dynamic two-factor verification through client id/secret phrase mix and second issue kind of an advanced mark or OTP/dynamic access code through various modes (like SMS over cell phones or equipment token). An inserted Crypto-Biometric verification subject for ATM keeping money frameworks has been anticipated. The guaranteed user"s unique mark is required all through a dealings. The unique mark picture is scrambled by means of disorganized guide as in no time since it is caught, at that point transmitted to the focal server abuse respectively symmetrical key algorithmic principle. The mystery composing keys territory unit extracted from the irregular part appropriation in a crude picture of unique mark, some steady world options of finger impression as well as from pseudo arbitrary range generator. absolutely different| completely different $\}$ rounds of cycles utilize distinctive keys. The interpreting happens at the managing an account terminal abuse an comparable key. we've got officially outlined the key difficulties of on-line dealings that is principally security. The look of AN algorithmic standard with mix of run of the mill and propelled security will guarantees e-security misuse 3 layer security frameworks. These 3 layers are: 1: run of the mill E-security abuse Username and PIN.2: Biometric security misuse Fingerprint or Iris acknowledgment.3. Mobile security misuse GPS or versatile SMS.

\section{REFERENCES}

[1] Kumaravel A., Rangarajan K.,Algorithm for automaton specification for exploring dynamic labyrinths,Indian Journal of Science and Technology,V-6,I-SUPPL5,PP-4554-4559,Y-2013

[2] P. Kavitha, S. Prabakaran "A Novel Hybrid Segmentation Method with Particle Swarm Optimization and Fuzzy C-Mean Based On Partitioning the Image for Detecting Lung Cancer" International Journal of Engineering and Advanced Technology (IJEAT) ISSN: 2249-8958, Volume-8 Issue-5, June 2019

[3] Kumaravel A., Meetei O.N.,An application of non-uniform cellular automata for efficient cryptography,2013 IEEE Conference on Information and Communication Technologies, ICT 2013,V-,I-PP-1200-1205,Y-2013

[4] Kumarave A., Rangarajan K.,Routing alogrithm over semi-regular tessellations,2013 IEEE Conference on Information and Communication Technologies, ICT 2013,V-,I-,PP-1180-1184,Y-2013

[5] P. Kavitha, S. Prabakaran "Designing a Feature Vector for Statistical Texture Analysis of Brain Tumor" International Journal of Engineering and Advanced Technology (IJEAT) ISSN: 2249-8958, Volume-8
Issue-5, June 2019

[6] Dutta P., Kumaravel A.,A novel approach to trust based identification of leaders in social networks,Indian Journal of Science and Technology,V-9,I-10,PP--,Y-2016

[7] Kumaravel A., Dutta P.,Application of Pca for context selection for collaborative filtering,Middle - East Journal of Scientific Research,V-20,I-1,PP-88-93,Y-2014

[8] Kumaravel A., Rangarajan K.,Constructing an automaton for exploring dynamic labyrinths,2012 International Conference on Radar, Communication and Computing, ICRCC 2012,V-,I-,PP-161-165,Y-2012

[9] P. Kavitha, S. Prabakaran "Adaptive Bilateral Filter for Multi-Resolution in Brain Tumor Recognition" International Journal of Innovative Technology and Exploring Engineering (IJITEE) ISSN: 2278-3075, Volume-8 Issue-8 June, 2019

[10] Kumaravel A.,Comparison of two multi-classification approaches for detecting network attacks, World Applied Sciences Journal,V-27,I-11,PP-1461-1465,Y-2013

[11] Tariq J., Kumaravel A.,Construction of cellular automata over hexagonal and triangular tessellations for path planning of multi-robots,2016 IEEE International Conference on Computational Intelligence and Computing Research, ICCIC 2016,V-,I-,PP--,Y-2017

[12] Sudha M., Kumaravel A.,Analysis and measurement of wave guides using poisson method,Indonesian Journal of Electrical Engineering and Computer Science,V-8,I-2,PP-546-548,Y-2017

[13] Ayyappan G., Nalini C., Kumaravel A.,Various approaches of knowledge transfer in academic social network, International Journal of Engineering and Technology,V-,I-,PP-2791-2794,Y-2017

[14] Kaliyamurthie, K.P., Sivaraman, K., Ramesh, S. Imposing patient data privacy in wireless medical sensor networks through homomorphic cryptosystems 2016, Journal of Chemical and Pharmaceutical Sciences 92.

[15] Kaliyamurthie, K.P., Balasubramanian, P.C. An approach to multi secure to historical malformed documents using integer ripple transfiguration 2016 Journal of Chemical and Pharmaceutical Sciences 92.

[16] A.Sangeetha,C.Nalini," Semantic Ranking based on keywords extractions in the web", International Journal of Engineering \& Technology, 7 (2.6) (2018) 290-292

[17] S.V.GayathiriDevi,C.Nalini,N.Kumar,"An efficient software verification using multi-layered software verification tool "International Journal of Engineering \& Technology, 7(2.21)2018 454-457

[18] C.Nalini,ShwtambariKharabe,"A Comparative Study On Different Techniques Used For Finger - Vein Authentication", International Journal Of Pure And Applied Mathematics, Volume 116 No. 82017 327-333, Issn: 1314-3395

[19] M.S. Vivekanandan and Dr. C. Rajabhushanam, "Enabling Privacy Protection and Content Assurance in Geo-Social Networks", International Journal of Innovative Research in Management, Engineering and Technology, Vol 3, Issue 4, pp. 49-55, April 2018.

[20] Dr. C. Rajabhushanam, V. Karthik, and G. Vivek, "Elasticity in Cloud Computing", International Journal of Innovative Research in Management, Engineering and Technology, Vol 3, Issue 4, pp. 104-111, April 2018.

[21] K. Rangaswamy and Dr. C. Rajabhushanamc, "CCN-Based Congestion Control Mechanism In Dynamic Networks", International Journal of Innovative Research in Management, Engineering and Technology, Vol 3, Issue 4, pp. 117-119, April 2018.

[22] Kavitha, R., Nedunchelian, R., "Domain-specific Search engine optimization using healthcare ontology and a neural network backpropagation approach", 2017, Research Journal of Biotechnology, Special Issue 2:157-166

[23] Kavitha, G., Kavitha, R., "An analysis to improve throughput of high-power hubs in mobile ad hoc network", 2016, Journal of Chemical and Pharmaceutical Sciences, Vol-9, Issue-2: 361-363

[24] Kavitha, G., Kavitha, R., "Dipping interference to supplement throughput in MANET" , 2016, Journal of Chemical and Pharmaceutical Sciences, Vol-9, Issue-2: 357-360

[25] Michael, G., Chandrasekar, A.,"Leader election based malicious detection and response system in MANET using mechanism design approach", Journal of Chemical and Pharmaceutical Sciences(JCPS) Volume 9 Issue 2, April - June 2016

[26] Michael, G., Chandrasekar, A.,"Modeling of detection of camouflaging worm using epidemic dynamic model and power spectral density", Journal of Chemical 


\section{Applying Cryptography In E-Banking Security}

and Pharmaceutical Sciences(JCPS) Volume 9 Issue 2, April - June 2016

[27] Pothumani, S., Sriram, M., Sridhar, J., Arul Selvan, G., Secure mobile agents communication on intranet,Journal of Chemical and Pharmaceutical Sciences, volume 9, Issue 3, Pg No S32-S35, 2016

[28] Pothumani, S., Sriram, M., Sridhar , Various schemes for database encryption-a survey, Journal of Chemical and Pharmaceutical Sciences, volume 9, Issue 3, Pg NoS103-S106, 2016

[29] Pothumani, S., Sriram, M., Sridhar, A novel economic framework for cloud and grid computing, Journal of Chemical and Pharmaceutical Sciences, volume 9, Issue 3, Pg No S29-S31, 2016

[30] Priya, N., Sridhar, J., Sriram, M. "Ecommerce Transaction Security Challenges and Prevention Methods- New Approach" 2016 ,Journal of Chemical and Pharmaceutical Sciences, JCPS Volume 9 Issue 3.page no:S66-S68 .

[31] Priya, N.,Sridhar,J.,Sriram, M."Vehicular cloud computing security issues and solutions" Journal of Chemical and Pharmaceutical Sciences(JCPS) Volume 9 Issue 2, April - June 2016

[32]

[33] Priya, N., Sridhar, J., Sriram, M. "Mobile large data storage security in cloud computing environment-a new approach" JCPS Volume 9 Issue 2. April - June 2016

[34] Anuradha.C, Khanna.V, "Improving network performance and security in WSN using decentralized hypothesis testing "Journal of Chemical and Pharmaceutical Sciences(JCPS) Volume 9 Issue 2, April - June 2016.

[35] Anuradha.C, Khanna.V, "A novel gsm based control for e-devices" Journal of Chemical and Pharmaceutical Sciences(JCPS) Volume 9 Issue 2, April - June 2016 .

[36] Anuradha.C, Khanna.V, "Secured privacy preserving sharing and data integration in mobile web environments " Journal of Chemical and Pharmaceutical Sciences(JCPS) Volume 9 Issue 2, April - June 2016.

[37] Sundarraj, B., Kaliyamurthie, K.P. Social network analysis for decisive the ultimate classification from the ensemble to boost accuracy rates 2016 International Journal of Pharmacy and Technology 8

[38] Sundarraj, B., Kaliyamurthie, K.P. A content-based spam filtering approach victimisation artificial neural networks 2016 International Journal of Pharmacy and Technology 83 .

[39] Sundarraj, B., Kaliyamurthie, K.P. Remote sensing imaging for satellite image segmentation 2016 International Journal of Pharmacy and Technology $8 \quad 3$.

[40] Sivaraman, K., Senthil, M. Intuitive driver proxy control using artificial intelligence 2016 International Journal of Pharmacy and Technology $8 \quad 4$.

[41] Sivaraman, K., Kaliyamurthie, K.P. Cloud computing in mobile technology 2016 Journal of Chemical and Pharmaceutical Sciences 92.

[42] Sivaraman, K., Khanna, V. Implementation of an extension for browser to detect vulnerable elements on web pages and avoid click jacking 2016 Journal of Chemical and Pharmaceutical Sciences 92.

\section{AUTHORS PROFILE}
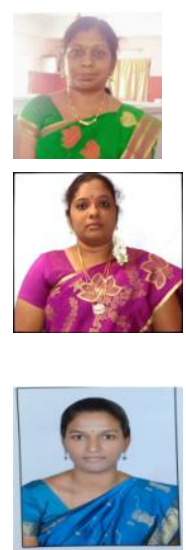

Nikita Sharma, Student, Department of Computer
Science \& Engineering, Bharath Institute of Higher Education and Research, Chennai, India

N.Priya Assistant Professor, Department of Computer Science \& Engineering, Bharath Institute of Higher Education and Research, Chennai, India

P.Nandhini, Assistant Professor, Department of Computer Science \& Engineering, Bharath Institute of Higher Education and Research, Chennai, India

D.Jeyapriya, Assistant Professor, Department of Computer Science \& Engineering, Bharath Institute of Higher Education and Research, Chennai, India 